\title{
Олександр БАРАНОВСЬКИЙ
}

доктор економічних наук, професор, Університет банківської справи, Львів, Україна, bai.professor@gmail.com

ORCID ID: 0000-0002-5505-5098

\section{Тетяна ПУТІНЦЕВА}

аспірант, Університет банківської справи, Львів, Україна, t.putintseva111@gmail.com

ORCID ID: 0000-0002-7640-7080

\section{ФОРМУВАННЯ КОМПАЕКСНОЇ ПРОГРАМИ ЗАБЕЗПЕЧЕННЯ ФІНАНСОВОЇ БЕЗПЕКИ КОМЕРЦІЙНИХ БАНКІВ УКРАЇНИ}

Вступ. Функціонування комерційних банків (КБ) має бути безпечним, позаяк поняття "безпека" з грецької - володіння ситуацією, тобто повний контроль $і$ забезпечення дієвості/ефрективності всіх аспектів діяльності КБ. Відсутність дієвої системи фрінансової безпеки КБ (ФБКБ) спричиняє нестійкість банківської діяльності, зростання тінізації відносин у банківській сфрері, унеможливлює належне виконання свого фрункціонального призначення, негативно позначається на діяльності підприємств реального сектору національної економіки та життєдіяльності будь-якої країни загалом. Відтак, формуванню зазначеної системи необхідно приділяти повсякденну увагу науковців і практиків, владних структур, регуляторів ринку банківських послуг, саморегулівних організацій i, безумовно, КБ. Важливо обгрунтувати вплив ліквідності на ФБКБ, що має знайти чільне місце у Комплексній програмі забезпечення ФБКБ.

Мета - визначити напрями підвищення ролі ліквідності КБ у забезпеченні ФБКБ під час розробки Комплексної програми забезпечення ФБКБ.

Результати. Висвітлені сутність ФБКБ та ії різновиди, а також напрями підвищення ролі ліквідності банківських установ у забезпеченні ФБКБ під час розробки Комплексної програми забезпечення ФБКБ.

Методи. Використано методи аналогій, декомпозиції та узагальнення, експертних оцінок, ситуаційного та логічного аналізу, концептуального моделювання.

Висновки. Підвищення ролі ліквідності КБ у забезпеченні їх ФБ можна досягти за рахунок розробки й реалізації Комплексної програми забезпечення ФБКБ України, в якій досліджувана проблематика має посісти чільне місце. Відтак подальших поглиблених досліджень потребують розглянуті положення й пропозиції.

Ключові слова: комерційний банк, ліквідність, управління ліквідністю, фрінансова безпека, фрінансова безпека комерційного банку.

Рис.: 3, бібл.: 12.

() Олександр Іванович Барановський, Тетяна Володимирівна Путінцева, 2021 


\section{Александр БАРАНОВСКИЙ}

доктор экономических наук, профрессор, Университет банковского дела, Львов, Украина

\section{Татьяна ПУТИНЦЕВА}

аспирант, Университет банковского дела, Львов, Украина

\section{ФОРМИРОВАНИЕ КОМПИЕКСНОЙ ПРОГРАММЫ ОБЕСПЕЧЕНИЯ ФИНАНСОВОЙ БЕЗОПАСНОСТИ КОММЕРЧЕСКИХ БАНКОВ УКРАИНЫ}

Введение. Функционирование коммерческих банков (КБ) должно быть безопасным, так как понятие "безопасность" с греческого - владение ситуацией, то есть полный контроль и обеспечение действенности/эффрективности всех аспектов деятельности банковских учреждений. Отсутствие действенной системы фринансовой безопасности КБ (ФБКБ) порождает неустойчивость банковской деятельности, рост тенизации отношений в банковской сфрере, делает невозможным надлежащее исполнение своего функционального назначения, негативно сказывается на деятельности предприятий реального сектора национальной экономики и жизнедеятельности любой страны в целом. Поэтому фрормированию указанной системы должно уделяться постоянное внимание ученых и практиков, властных структур, регуляторов рынка банковских услуг, саморегулирующих организаций и, безусловно, КБ. Важно обосновать влияние ликвидности на ФБКБ, что должно занять подобающее место в Комплексной программе обеспечения ФБКБ.

Цель - определить направления повышения роли ликвидности КБ в обеспечении ФБКБ при разработке Комплексной программы обеспечения ФБКБ.

Результаты. Освещены сущность ФБКБ и ее разновидности, а также направления повышения роли ликвидности КБ в обеспечении ФБКБ при разработке Комплексной программы обеспечения ФБКБ.

Методы. Использованы методы аналогий, декомпозиции и обобщения, экспертных оценок, ситуационного и логического анализа, концептуального моделирования.

Выводы. Усиление роли ликвидности КБ в обеспечении их ФБ можно достичь за счет разработки и реализации Комплексной программы обеспечения ФБКБ Украины, в которой исследуемой проблематике должно быть отведено важное место. Дальнейших углубленных исследований требуют рассмотренные положения и предложения.

Ключевые слова: коммерческий банк, ликвидность, управление ликвидностью, финансовая безопасность, фринансовая безопасность коммерческого банка.

\section{Oleksandr BARANOVSKYI}

Dr. Sc. (Economics), Prof., Banking University, Lviv, Ukraine, bai.professor@gmail.com

ORCID ID: 0000-0002-5505-5098

\section{Tetiana PUTINTSEVA}

Postgraduate student, Banking University, Lviv, Ukraine, t.putintseva111@gmail.com ORCID ID: 0000-0002-7640-7080

\section{FORMATION OF A COMPREHENSIVE PROGRAM FOR PROVIDING FINAN- CIAL SECURITY OF COMMERCIAL BANKS OF UKRAINE}

Introduction. The operation of commercial banks (CB) must be safe. The lack of an effective system of financial security $C B$ (FSCB) causes instability of banking, increasing shadowing of rela-tions in the banking sector, makes impossible for the $C B$ to properly perform its 
functional purpose, negatively affects the real sector of the national economy and life in any country. Therefore, the formation of this system should be given daily attention of scientists and practitioners, government agencies, market regulators of banking services and self-regulatory organizations and CB. It is important to justify the impact of liquidity on the FSCB, which should find a prominent place in the Comprehensive program of the FSCB.

The purpose of the article is to determine the directions of increasing the role of CB liquidity in providing the FSCB in the development of the Comprehensive program for the provision of the FSCB.

Results. The article highlights the essence of the FSCB and its varieties, as well as ways to increase the role of liquidity of banking institutions in providing the FSCB in the development of a Comprehensive program to provide the FSCB.

Conclusions. Methods of analogies, decomposition and generalization, expert assessments, situational and logical analysis, conceptual modeling are used.

Keywords: acommercial bank, liquidity, liquidity management, financial security, financial security of the commercial banks.

JEL Classification: G21.

Постановка проблеми. Для повноцінного виконання КБ свого функціонального призначення, забезпечення стабільного й безпечного фрункціонування необхідна дієва система забезпечення ФБКБ. Ії фрормуванню слід приділяти повсякденну увагу науковців і практиків, владних структур, регуляторів ринку банківських послуг, саморегулівних організацій і КБ.

Вагоме місце у розбудові системи забезпечення ФБКБ належить дотриманню оптимальних параметрів ліквідності. Відтак, дослідження впливу ліквідності банківських установ на ФБКБ $є$ доволі актуальним.

Аналіз останніх досліджень і публікацій. Проблематику сутності ФБКБ, її забезпечення та впливу ліквідності КБ на нього в своїх працях розглядали такі вітчизняні й зарубіжні дослідники, як: А. Вороков, В. Гайдук, Н. Гайдук, [1], С. Родченко [2], Н. Наточеєва [3], В. Богомолов [4], Т. Болгар [5], Д. Артеменко [6], С. Землячов [7], І. Янковський [8], С. Алексєєва [9], І. Вишняков, [10], О. Симановський [11], О. Морозова [12]. Проте дотепер відсутні устале- ні уявлення про місце і роль ліквідності КБ у забезпеченні ФБКБ.

Метою статті $€$ визначення напрямів підвищення ролі ліквідності банківських установ у забезпеченні ФБКБ під час розробки Комплексної програми забезпечення ФБКБ.

Виклад основного матеріалу дослідження. Для досягнення поставленої мети, насамперед, слід визначитися з розумінням ФБКБ. На нашу думку, під ФБКБ слід розуміти:

- об'єкт управління, зумовлений за наявного його ресурсоакумулюючого потенціалу фінансовим станом КБ, що забезпечує його ефективну життєдіяльність і поступальний розвиток, мінімізацію загроз/ризиків його активам, фінансовим незалежності/стійкості/стабільності та надійності, і результат управлінських впливів на здійснення банківських операцій, реалізацію банківських продуктів і надання банківських послуг та зниження волатильності ціноутворення на них;

- стан захищеності фінансових інтересів/ майнових прав власників, акціонерів, 
топ-менеджменту, персоналу, клієнтів/ контрагентів.

В. Гайдук, А. Вороков і Н. Гайдук виокремлюють такі структурні елементи ФБКБ, як ресурсна, кредитна, інвестиційна, валютна безпеки, безпеки розрахункових операцій і економічної банківської інформації [1]. Однак останню складову, на наш погляд, не можна вважати структурним елементом ФБКБ, оскільки вона стосується всієї життєдіяльності КБ.

С. Родченко розглядає такі функціональні компоненти ФБКБ, як: капіталоресурсна (безпека пасивних операцій), кредитно-інвестиційна (безпека активних операцій), фрінансово-результативна, валютна та вартісно-грошова безпеки [2]. Утім, якщо перші чотири із зазначених компонент заперечень не викликають, то вартісно-грошова безпека, на наш погляд, має доволі абстрактний характер, оскільки не характеризує конкретний аспект функціонування КБ, тому що грошові потоки є неодмінним атрибутом усіх його елементів.

В умовах фрінансової глобалізації й економічної інтеграції слід ураховувати й ФБКБ у сфрері міжнародних розрахунків і платежів, під якою розуміють [3] розробку і реалізацію заходів безпеки з запобігання впливу загроз на КБ і системи з контролем надійності, ліквідності, взаємозв'язків самих систем, а також якості розрахункового обслуговування їх клієнтів на основі виконання стандартів міжнародних платежів з урахуванням впливу деструктивних чинників.

На наш погляд, структурними елементами ФБКБ є: ресурсоутворювальна, депозитна, кредитна, валютна, боргова, інвестиційна, податкова безпеки, безпека доходів і витрат, безпека у сфері міжнародних розрахунків і платежів, безпека ліквідності.

Під безпекою ліквідності слід розуміти такий стан ліквідності КБ, що характеризується ії̈ достатністю, збалансованістю та стійкістю/стабільністю. Значущість виокремлення цієї складової ФБКБ зумовлюється тим, що КБ разом з ЦБ у країнах з банкоцентричним фрінансовим сектором (до яких належить і Україна) $є$ головними постачальниками ліквідності господарського комплексу, а ліквідність окремих КБ $є$ основою забезпечення ліквідності (а відтак, і ФБ) БС загалом, а також гарантом платоспроможності, дохідності (за ії оптимальних параметрів), надійності, фрінансових стійкості/стабільності банківських установ.

Крім того, безпека ліквідності КБ, впливаючи на його платоспроможність, фрінансові стійкість/стабільність, надійність і конкурентоспроможність, зумовлює його ресурсоутворювальну, депозитну, кредитну, валютну, боргову, інвестиційну безпеки та безпеку доходів і витрат, безпеку у сфері міжнародних розрахунків і платежів, а відтак, і ФБКБ загалом. Водночас, за надлишкової ліквідності сукупності КБ остання може провокувати зниження рівня валютної й інфляційної безпек держави.

Можна стверджувати про вагомі місце і роль ліквідності КБ у забезпеченні їх ФБ. Це доводить, насамперед, фрормулювання окремими дослідниками сутності економічної безпеки (однією з найважливіших складових якої $є$ ФБ) як здатності економічної системи (господарюючого суб'єкта, підприємства) планово розвиватися, зберігаючи фрінансово-економічну стійкість, ліквідність і здатність до розширеного відтворення [4, с. 32], та твердження, що:

- до основних важелів, за допомогою яких КБ може управляти ФБ, можна віднести: капітал, залучені і запозичені ресурси, валютну позицію, активи, ліквідність і платоспроможність, банківські продукти й операції, фрінансові результати (прибуток, доходи), заробітну плату, податки [5, с. 98]; 
- фрінансова складова економічної безпеки банківської діяльності $€$ комплексом заходів із досягнення максимально можливої платоспроможності й стійкості КБ, ліквідності його балансу, ефективної структури капіталу та найприбутковіших напрямів його вкладень, що досягається шляхом чіткого стратегічного і тактичного планування, аналізу і запобігання загрозам фрінансового характеру. А розв'язання конфрлікту між ліквідністю і прибутковістю полягає в прийнятті керівництвом стратегічних рішень із застосуванням захисних функцій технологій фрінансового менеджменту, що забезпечують баланс операцій з високою прибутковістю разом з раціональною політикою кредитування i помірністю у вкладаннях коштів у довгострокові ЦП. Така позиція, з точки зору забезпечення ФБ банківської діяльності, дасть змогу КБ поєднувати високу прибутковість із високою ліквідністю активів [6];

- ризики неліквідності/порушення/утрати/ зниження/недостатньої (від'ємної, дефіцитної) /надлишкової/незбалансованої/неможливості отримання грошових коштів/втрати доходу внаслідок неспроможності чи неможливості своєчасно відрегулювати свою ліквідну позицію/ збитків через необхідність здійснення швидкої конверсії фрінансових активів/ нерівномірного розподілу ліквідності внаслідок особливостей доступу до неї вітчизняних КБ - "це небезпека виникнення проблеми недостатності власних, залучених та позичених коштів для забезпечення виконання власних зобов'язань, що визначається величиною недоотриманих доходів за вимушеного продажу активів за поточною вартістю для покриття розриву ліквідності, або величиною надлишкових витрат, понесених у результаті вимуше- ного залучення пасивів для вирішення проблем, пов'язаних з нестачею ліквідних коштів" [7, с. 79];

- саме ефективне управління ліквідністю дає змогу мінімізувати ризики одержання збитків, максимізувати прибуток, забезпечити стійкий й стабільний розвиток КБ [8];

- норми, що регламентують обов'язкові фрінансові нормативи і резервні вимоги, що забезпечують ліквідність БС, $є$ найважливішим елементом саме фрінансовоправових засад банківської безпеки [9].

Натомість, дисбаланс ліквідності, її зниження та загроза фрінансових втрат, пов'язаних 3 кредитуванням, $€$ одними 3 найсуттєвіших загроз ФБКБ.

Ліквідність відображає всі аспекти діяльності та $€$ індикативною ознакою фінансово здорового КБ, тоді як ознаки її нестачі свідчать про зворотне. Відповідно, необхідний і достатній обсяг ліквідних активів (оптимум) перебуває між мінімальним обсягом грошових коштів для проведення касових операцій і обсягом, достатнім для покриття всіх фінансових зобов'язань [10, c. 24, 26].

Для підвищення ролі ліквідності банківських установ у забезпеченні ФБКБ НБУ, НАБУ, АУБ із залученням провідних науковців і експертів необхідно розробити Комплексну програму забезпечення фрінансової безпеки комерційних банків України, яка, поряд з іншими аспектами банківської діяльності, передбачала б:

- розробку дієвої ресурсної політики КБ (підвищення рівня ресурсоутворювальної безпеки);

- оптимальне поєднання інструментів надання, абсорбування ліквідності і універсальних інструментів (обов'язкове резервування, ставка рефрінансування, операції на валютному ринку, валютні свопи, операції Міністерства фрінансів 
України, абсорбування ліквідності за профріциту Державного бюджету України й іiї влиття за його десріциту та тимчасового розміщення вільних бюджетних коштів на депозитах у КБ (підвищення рівня безпеки ліквідності);

- реформування системи гарантування банківських вкладів з поширенням ії на вклади юридичних осіб і індивідуальних підприємців (підвищення рівня депозитної безпеки);

- розробку КМУ і НБУ державної програми зі стимулювання ощадного процесу, яка охоплювала б напрями підвищення ощадоспроможності населення і господарюючих суб'єктів, підходи до диференціації ставок за коротко- і довгостроковими депозитами (підвищення рівня депозитної безпеки);

- підвищення вимог до забезпечення ліквідності системно значущих КБ (підвищення рівня безпеки ліквідності);

- визначення особливостей забезпечення ліквідності КБ-оригінаторів, що мають активи, придатні для сек'юритизації (однорідні за строками, цілями і обсягами запозичення, ймовірністю дефолту) (підвищення рівнів інвестиційної й боргової безпек);

- забезпечення доступу КБ до залишків на рахунках, платежів клієнтів/ контрагентів, кредитів НБУ, запозичень на міжбанківському кредитному і фондовому ринках (підвищення рівнів інвестиційної/ боргової безпек КБ і безпеки розрахункових операцій);

- розробку індикаторів (обґрунтування їх порогових значень), які свідчать про вплив ліквідності на ФБКБ та $є$ основою з урахуванням зміни їх значень для вироблення комплексу заходів у плановому періоді за допомогою методу “дерева цілей” і вибору їх оптимального варіанта завдяки використанню математичного моделювання (підвищення рівня безпеки ліквідності);

- здійснення компаративного аналізу часу перебування платежів у чергах, заторів/ блокування платежів, механізмів управління ліквідністю у порівнюваних платіжних системах (підвищення рівнів безпек розрахункових операцій і ліквідності);

- поліпшення ризик-менеджменту КБ загалом та акумулювання необхідної інформації, ідентифрікацію, кількісний аналіз, оцінку наслідків настання й розробку конкретних заходів з мінімізації/ запобігання ризикам неліквідності/ порушення/ утрати/зниження/недостатньої (від'ємної)/ надлишкової/ незбалансованої/неможливості отримання грошових коштів/втрати доходу внаслідок неспроможності чи неможливості КБ своєчасно відрегулювати свою ліквідну позицію/ збитків через необхідність здійснення швидкої конверсії фрінансових активів/ нерівномірного розподілу ліквідності КБ, які мають вживати НБУ, саморегулівні організації на ринку банківських послуг України та безпосередньо КБ, хеджування та контролінгу цих ризиків у банківських установах (підвищення рівня безпеки ліквідності);

- удосконалення моніторингу кредитного (на основі постійного відстеження відношення кредитів до активів - що воно вище, то вище схильність до ризику неплатоспроможності позичальників КБ; відношення прибутку до активів - що воно нижче, то більше ймовірність здійснення операцій з підвищеним рівнем ризику й дохідності, а що вище, то наявність здійснених вкладень з підвищеним рівнем ризику; приросту активів відносно попереднього року, що може свідчити про надмірну експансію; приросту кредитів відносно попереднього року, що може свідчити про надмірну експансію і втрату ліквідності; відношення 
отриманих відсотків і лізингових платежів до обсягу наданих кредитів - що вища середня дохідність лізингових операцій КБ, то вищий кредитний ризик; відношення обсягу повернених кредитів і відсотків до загального обсягу наданих кредитів - що вище повернення кредитів, то більш зваженою є кредитна політика; частки позитивно класифікованих кредитів - що вища ця частка, то вище ліквідність КБ), депозитного (частки депозитів, що перевищує 200000 грн - що вище їх сума, то більш нестійкий КБ), ринкового, операційного (частки операційних витрат в загальному обсязі витрат і середня заробітна плата характеризують ступінь контролю керівництва за витратами банківської установи), репутаційного ризиків, які можуть позначатися на виборі загальної стратегії управління їх ліквідністю (підвищує рівень кредитної безпеки і безпеки доходів і витрат);

- визначення інструментарію відновлення ліквідності (розробка плану заходів (збільшення капіталу, реструктуризація депозитів 3 коротко- у довгострокові, переведення субординованих кредитів, облікованих векселів, акцій, облігацій до складу формально ліквідних активів (короткострокових вимог); залучення короткострокових кредитів/депозитів, включаючи міжбанківські; залучення довгострокових кредитів/депозитів; обмеження/ припинення кредитування на певний термін; скорочення/припинення певних видів витрат) (зміцнення ресурсоутворювальної/депозитної/кредитної безпек/ безпеки ліквідності);

- формування системи колективної безпеки (СКБ) /системи страхування КБ ризиків утрат, що виникають у зв'язку зі стресами системного походження з метою оперативної оцінки потреб у ліквідності і рівня втрат в умовах системного стресу на предмет можливості їх заповнення/ покриття (виходячи з причин виникнення) коштами Фонду СКБ, що формується з регулярних диференційованих внесків КБ - учасників СКБ з урахуванням необхідності збереження нормальних умов функціонування (загальна базова ставка відрахувань), а також індивідуального рівня фрінансової стійкості КБ, насамперед, якості управління прийнятими ризиками (додаткова індивідуальна ставка), а також державних коштів, розмір яких визначається відповідно до завдань формування цільової величини фонду [11, с. 23-24] (підвищення рівня безпек доходів і витрат/ліквідності);

- створення індивідуальних добровільних страхових фондів із залученням як гаранта повернення вкладів збанкрутілих КБ ЄБРР, який у разі неспроможності КБ відповідати за своїми зобов'язаннями, контролюватиме кредитний портфель й інші активи, еквівалентні обсягу гарантованих депозитів та за необхідності продасть активи для виконання зобов'язань перед вкладниками (забезпечення депозитної/кредитної безпек);

- підвищення вимог КБ до фінансового стану і наявності застави/гарантій/ поручительств роздрібних і корпоративних позичальників (забезпечення кредитної безпеки);

- солідарну фрінансову підтримку соціально значущих КБ, у разі виникнення у них проблем з ліквідністю, за рахунок належного рефінансування їх НБУ та обов'язкової участі акціонерів банківських установ (забезпечення ресурсоутворювальної/кредитної/боргової безпек/ безпеки ліквідності);

- напрями забезпечення фінансової стабільності КБ, їх спроможності поглинання майбутніх імовірних збитків (забезпечення безпеки доходів і витрат); 
- запровадження адаптивних до конкретної макроекономічної ситуації загалом і ситуації на вітчизняному ринку банківських послуг норм обов'язкового резервування за вкладами в іноземній валюті (забезпечення депозитної/валютної безпек);

- скасування/зменшення обов'язкового оподаткування відсотків за строковими банківськими депозитами (забезпечення депозитної безпеки);

- вимоги до розкриття інформації з управління ліквідністю.

Важливе значення у Комплексній програмі забезпечення ФБКБ України має належати створенню дієвої системи ризикменеджменту КБ у сорері формування, розподілу й використання їх ліквідності.

Убезпеченню від ризиків неліквідності/ утрати/зниження/недостатньої (від'ємної) ліквідності/неможливості отримання грошових коштів/збитків через необхідність здійснення швидкої конверсії фрінансових активів, а відтак, підвищенню ФБКБ сприятиме, зокрема:

- підвищення капіталізації вітчизняних КБ та максимізація їх ринкової вартості;

- розчистка балансу за допомогою переведення на самостійний баланс конкретних видів діяльності;

- виважена депозитна політика, яка має передбачати стабілізацію депозитних порторелів, розширення лінійки депозитних продуктів, зокрема, за рахунок використання їх конвертаційних різновидів;

- скорочення зобов'язань на вимогу, перегрупування пасивів за строками; обмеження трансформації строків угод КБ, пролонгація зобов'язань;

- додаткові внески засновників;

- формування попиту і відкриття КБ для приросту їх ресурсної бази індивідуальних пенсійних рахунків;

- збільшення ліквідних активів;
- застосування диференційованої ставки обов'язкових нормативів залежно від терміну залучення грошових коштів;

- заборона невиправданого використання грошових коштів клієнтів на проекти 3 підвищеним ризиком; зниження непродуктивних витрат;

- зменшення втрат кредитно-інвестиційних ресурсів, зумовлених проблемними кредитами, відпливом капіталу з КБ;

- - зниження норм обов'язкового резервування за вкладами в іноземній валюті у разі виникнення кризових явищ;

- диференціація максимальних розмірів страхового відшкодування ФГВФО депозитів з пріоритетом значного збільшення цього показника за довгостроковими депозитами;

- створення додаткових стимулів для КБ залучати кошти з надійних джерел;

- розширення Міністерством фрінансів України переліку КБ, для яких доступні тимчасово вільні бюджетні кошти, та збільшення лімітів їх розміщення в цих банківських установах;

- укладання НБУ угод з КБ про компенсацію частини витрат/збитків останніх за угодами на міжбанківському ринку шляхом розміщення регулятором компенсаційних депозитів і списання 3 нього коштів у разі відкликання ліцензії у контрагента КБ;

- недопущення втрати коштів за неприбуткового продажу активів;

- обмеження вартості фрінансових ресурсів, які залучають КБ;

- закриття торгових й інвестиційних позицій;

- перехід до FTP-моделі (трансфрертного ціноутворення) на базі методу узгодженої ставки, що дасть змогу вибудувати консолідовану систему управління ефективністю бізнесів [12, с. 79]; 
- запровадження спеціальних механізмів економії ліквідності (введення черг платіжних доручень, що надходять, які дадуть змогу відтермінувати виконання платежу до поповнення рахунку платника; застосування алгоритмів проведення дво- та багатосторонніх взаємозаліків зустрічних вимог; установлення пріоритетності певних різновидів переказів);

- збільшення кількості діючих лімітів на банки-партнери, щоб у критичній ситуації мати додаткову можливість залучення ресурсів;

- упровадження на фінансовому ринку сучасних технологій заміщення боргових зобов'язань КБ довгостроковими цінними паперами з їх продажем на вторинному ринку й отриманням ліквідних грошових коштів;

- постійний моніторинг динаміки залучених фрінансових ресурсів за строками/ валютами/клієнтами/ціною/витратами;

- прогнозування ліквідності в короткостроковому періоді і зміни ринкового попиту;

- позбавлення КБ непрофрільних активів/ неліквідних бізнесів;

- мінімізація ризику втрати ліквідності за допомогою визначення значущості застави для заставодавця, диференціації портфеля застав, зіставлення параметрів і характеристик застави із структурою кредитного продукту (лімітування вимог до застави);

- розподіл ризику втрати ліквідності між банком і заставодавцем у разі зниження вартості заставного майна у забезпеченні кредитного зобов'язання завдяки залученню додаткового забезпечення;

- ефрективне використання всіх наявних фінансових ресурсів;

- посилення внутрішнього контролю й аудиту;

- підвищення рівня маркетингової діяльності з дослідження ринку банківських по- слуг, задоволення попиту клієнтів/контрагентів на наявні банківські продукти і послуги, розробки/впровадження нових банківських продуктів/інноваційних банківських технологій, розвитку альтернативних каналів продажів, поліпшення ціноутворення і рекламного забезпечення їх просування; демонстрації надійності КБ учасникам вітчизняного ринку банківських послуг; підвищення власного іміджу і моніторинг іміджу крупних клієнтів.

Заходи для підтримки ліквідності на належному рівні мають диференціюватись на: стандартні в умовах оптимальної ліквідності; заходи з виявлення дефріциту ліквідності та його усунення; з виявлення надлишку ліквідності та його абсорбування. Реалізація згаданих заходів підвищить рівень ресурсоутворювальної, депозитної, кредитної, валютної, боргової, інвестиційної, податкової безпек та безпеки доходів і витрат КБ і, безумовно, безпеки ліквідності, а також ФБКБ загалом.

Убезпеченню від ризику надлишкової ліквідності, а відтак, підвищенню ФБКБ сприятиме: перегляд депозитної політики; зростання кредитних продуктів; активізація діяльності на валютному і фондовому ринках; вихід на перспективні сегменти ринку банківських послуг України; установлення граничної ставки за депозитами фізичних осіб на рівні подвійної ставки рефінансування НБУ; передавання підрозділами КБ надлишку коштів його казначейству за загальною тарифною ставкою, з подальшим їх передаванням підрозділам, що відчувають їх дефіцит/розміщенням на фінансовому ринку (у цьому разі бізнес-підрозділи беруть на себе всі ризики, а дефріцит ліквідності на рівні банківської установи покривається за рахунок інструментів грошового ринку).

Для реалізації цього методу необхідна документована модель фрондування [12, с. 76]; застосування НБУ ощадних депози- 
тів, нот, репо-купівлі ЦП із зобов'язанням зворотного продажу), валютних свопів; придбання КБ ОВДП; здійснення НБУ операцій зворотного репо і заміщення банківських резервів своїми зобов'язаннями.

Вжиття зазначених заходів сприятиме підвищенню рівня ресурсоутворювальної, валютної, боргової, інвестиційної безпек, безпеки доходів і витрат КБ і, безумовно, безпеки ліквідності, а також ФБКБ загалом. У Комплексній програмі забезпечення ФБКБ України мають знайти своє відображення й підходи до формування системи управління безпекою ліквідності, яка, на наш погляд, має включати такі блоки у їх взаємозв'язку й взаємозумовленості, розташовані в наведеній послідовності (рис. 1):

- з'ясування чинників формування й використання ліквідності КБ, що зумовлюють його безпечне і стабільне функціонування й платоспроможність;

- формування мети управління безпекою ліквідності, що має полягати у забезпеченні поточної й перспективної рівноваги грошових потоків КБ за максимізації його прибутку й підвищення ринкової вартості, а також плануванні ліквідності для вжиття необхідних заходів до настання прогнозованих подій для зниження вартості залучення фінансових ресурсів завдяки обґрунтованому визначенню їх джерел й мінімізації надлишкових резервів; мінімізації негативних наслідків реалізації викликів/загроз/ризиків; формуванні позитивного іміджу у клієнтів/контрагентів;

- визначення завдань управління безпекою ліквідності, до яких слід віднести: діагностику стану його ліквідності; оцінку впливу на неї зовнішнього й внутрішнього середовищ; досконале управління активами/пасивами КБ/ вартістю ресурсів для забезпечення ліквідності; оптимальне управління ризиками; про- гнозування потреби у ліквідних засобах/рівня безпеки ліквідності;

- формування системи управління ризиками неліквідності/порушення/ утрати/ зниження/недостатньої (від'ємної, дефріцитної)/ надлишкової/ незбалансованої/ неможливості отримання грошових коштів/втрати доходу внаслідок неспроможності чи неможливості КБ своєчасно відрегулювати свою ліквідну позицію/ збитків через необхідність здійснення швидкої конверсії фінансових активів/ нерівномірного розподілу ліквідності/дезагрегації ліквідності балансу;

- організація управління: вимогами чистого рефрінансування (розробка графріків погашення й з'ясування перевищення/ дефіциту коштів на певні дати; визначення ліквідності у кризових ситуаціях за відсутності можливості пролонгації/ заміни значної частини його пасивів, погіршення ліквідності БС загалом); доступом на фінансові ринки; планування дій за непередбачуваних обставин;

- визначення основних етапів управління ризиками неліквідності/ порушення/ втрати/зниження/недостатньої (від'ємної, дефіцитної)/ надлишкової/незбалансованої/неможливості отримання грошових коштів/ втрати доходу внаслідок неспроможності чи неможливості КБ своєчасно відрегулювати свою ліквідну позицію/ збитків через необхідність здійснення швидкої конверсії фрінансових активів/ нерівномірного розподілу ліквідності/дезагрегації ліквідності балансу.

У згаданій комплексній програмі мають бути визначені і складові управління ліквідністю КБ для забезпечення їх ФБ загалом (рис. 2), серед яких, на наше переконання, слід виокремити:

- керуючу підсистему системи управління ліквідністю КБ - суб'єктів управління ліквідністю; 
3'ясування чинників формування й використання ліквідності КБ, що зумовлюють його стабільне функціонування й платоспроможність (чинники пропорційності руху активів і пасивів, дотримання визначальних співвідношень між ними: адекватність капіталу сукупному ризику активів; пропорційності активів і пасивів за строками залучення й розміщення, структур активів і депозитів; якості активів і пасивів за диверсифікованістю й ризиковістю; якості управління ліквідністю; репутації/рейтингів КБ в Україні

й закордоном; и екзогенні/макроекономічні чинники, що зумовлюють взаємозв'язок стану ліквідності БС і ліквідності даного КБ

\section{$\checkmark$}

Формування мети управління безпекою ліквідності КБ, що має полягати у забезпеченні поточної й перспективної рівноваги грошових потоків КБ за максимізації його прибутку й підвищення ринкової вартості, а також плануванні ліквідності для вжиття необхідних заходів до настання прогнозованих подій для зниження вартості залучення КБ фінансових ресурсів завдяки обгрунтованому визначенню їх джерел й мінімізації надлишкових резервів; мінімізації негативних наслідків реалізації викликів/загроз/ ризиків; формуванні позитивного іміджу у клієнтів/ контрагентів

\section{Формування системи управління безпекою ліквідності КБ для забезпечення його ФБ}

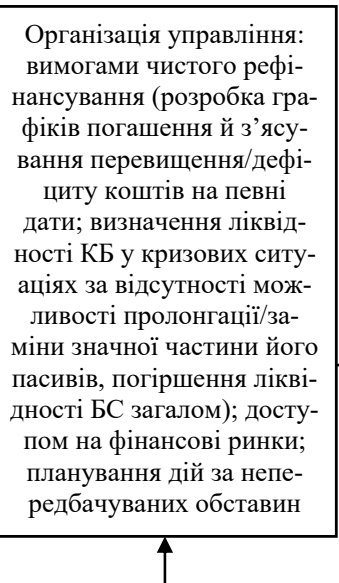

Формування системи управління ризи ками неліквідності/порушення/утрати/зниження/недостатньої (від'ємної,дефіцитної)/надлишкової/незбалансованої/неможливості отримання грошових коштів/втрати доходу внаслідок неспроможності чи неможливості КБ своєчасно відрегулювати свою ліквідну позицію/збитків через необхідність здійснення швидкої конверсії фінансових активів/нерівномірного розподілу ліквідності/дезагрегації ліквідності балансу КБ

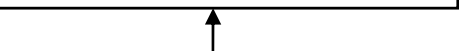

Визначення завдань управління безпекою ліквідності КБ, до яких слід віднести: діагностику стану його ліквідності; оцінку впливу на неї зовнішнього й внутрішнього середовищ; досконале управління активами/пасивами КБ/вартістю ресурсів для забезпечення ліквідності; оптимальне управління ризиками; прогнозування потреби КБ у ліквідних засобах/рівня безпеки ліквідності
Визначення основних етапів управління ризиками неліквідності/порушення/утрати/зниження/недостатньої (від'ємної, дефіцитної)/надлишкової/незбалансованої/неможливості отримання грошових коштів/втрати доходу внаслідок неспроможності чи неможливості КБ своєчасно відрегулювати свою ліквідну позицію/збитків через необхідність здійснення швидкої конверсії фінансових активів/нерівномірного розподілу ліквідності/дезагрегації ліквідності балансу КБ:

1) збір необхідної інформації (бази даних про динаміку різних показників ліквідності);

2) аналіз цієї інформації для оцінки зазначених ризиків (визначення чинників таких ризиків й імовірності прояву негативних подій з урахуванням сценаріїв стрес-тестування; пошук джерел необхідної інформації (автоматизовані системи КБ, фахові оцінки поведінки на ринку банківських послуг, рейтингові/консалтингові агентства, НБУ, НАБУ, АУБ);

3) визначення меж зон ризиків/іх градації параметрів чинників ризиків/відповідних індикаторів; аналіз оперативних даних, наслідків реалізації вищезазначених ризиків/оцінка розміру потенційних збитків від їх прояву;

4) облік і внутрішній контроль (стратегічний/поточний/оперативний) стану ліквідності КБ;

5) розробка заходів 3 мінімізації негативного прояву загроз/реалізації вищезазначених ризиків (з прямого контролю вхідних/вихідних грошових потоків, установлення лімітів на різновиди операцій КБ/контрагентів, їх перегляду; модернізації IT-інфраструктури, здійснення організаційних новацій) та оцінка ефективності їх застосування;

6) прогнозування стану ліквідності КБ/ його балансу/стану ліквідних активів/ грошових потоків/залучення коштів

\section{Рис. 1. Формування системи управління безпекою ліквідності комерційного банку} для забезпечення його фінансової безпеки*

* Побудовано авторами.
- керовану підсистему системи управлін- ня ліквідністю КБ - об'єкти управління ліквідністю;
- функціональну підсистему системи управління ліквідністю КБ - інструмен- ти управління ліквідністю;




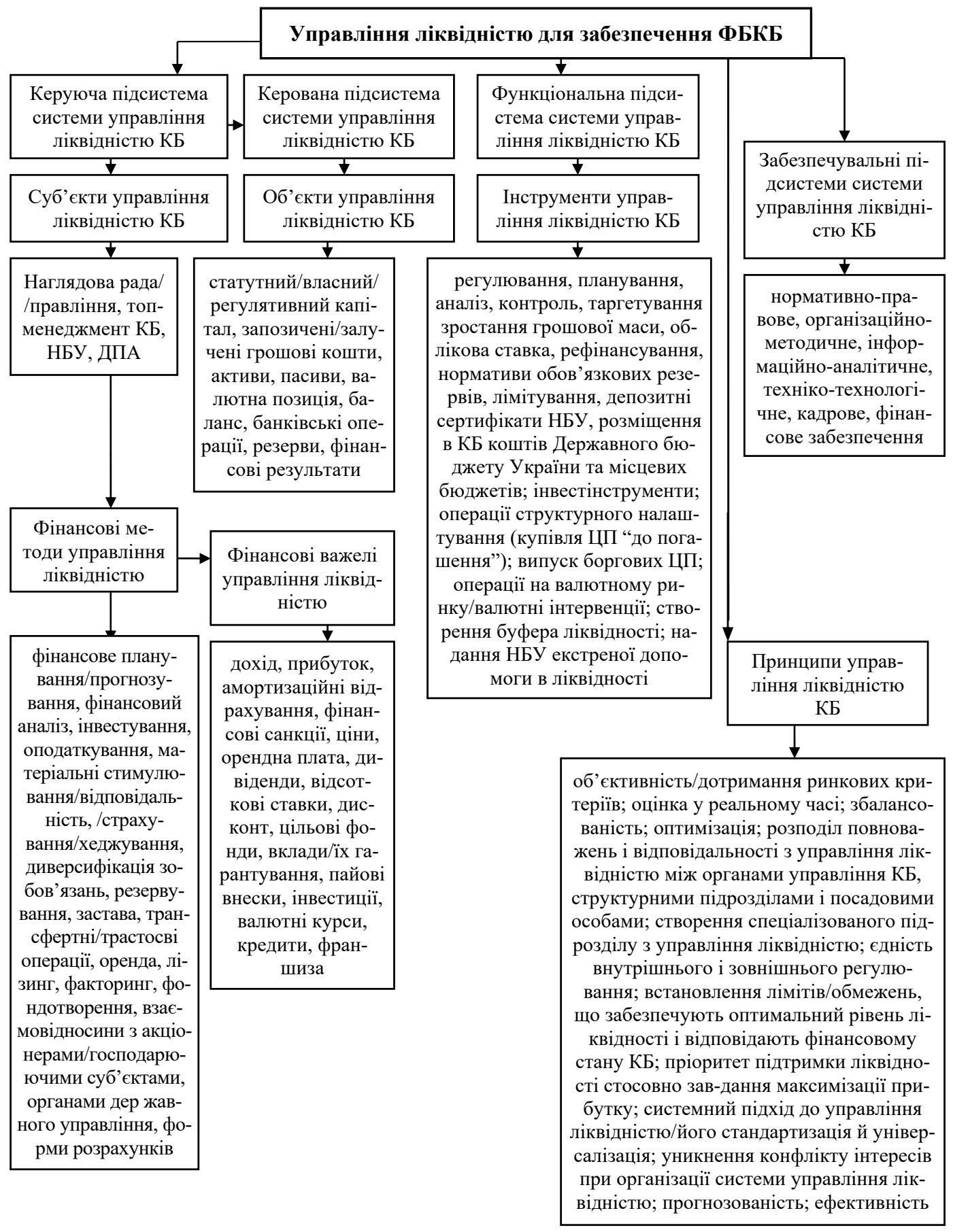

Рис. 2. Управління ліквідністю комерційного банку

* Побудовано авторами. для забезпечення його фінансової безпеки* 
- забезпечувальні підсистеми системи управління ліквідністю КБ - ресурсоутворювальної, депозитної, кредитної, валютної, боргової, інвестиційної, податкової безпек та безпеки доходів i витрат і, безумовно, безпеки ліквідності (рис. 3).

Висновки. Таким чином, підвищення ролі ліквідності КБ у забезпеченні їх
ФБ можна досягти за рахунок розробки й реалізації Комплексної програми забезпечення фінансової безпеки комерційних банків України, в якій досліджувана проблематика має посісти чільне місце. А відтак, подальших поглиблених досліджень потребують тезово розглянуті у статті положення й пропозиції.

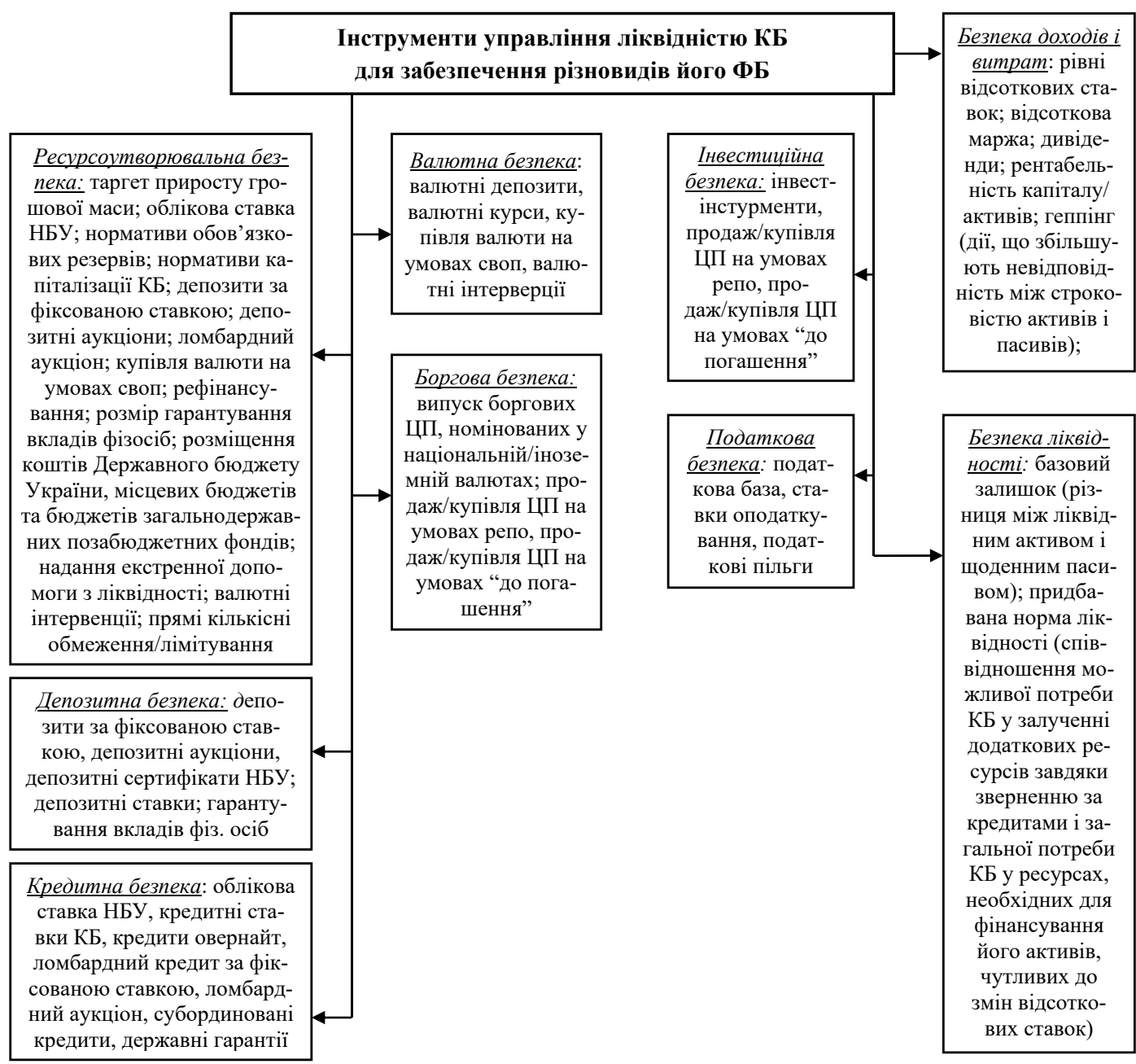

Рис. 3. Інструменти управління ліквідністю комерційного банку * Побудовано авторами. для забезпечення різновидів його фрінансової безпеки* 


\section{Список використаних джерел}

1. Гайдук В. И., Вороков А. Л., Гайдук Н. В. Финансовая безопасность коммерческих банков: критерии и индикаторы. Научный журнал КубГАУ. 2015. № 114. URL : http://ej.kubagro. ru/2015/10/pdf/06.pdf.

2. Родченко C. С. Вартісно-орієнтована стратегія забезпечення фрінансової безпеки комерційних банків : авторефр. дис. канд. екон. наук: 21.04.02. Харків, 2019. 26 с.

3. Наточеева Н. Н. Финансовая безопасность банков в сррере международных расчетов и платежей. Аудит и фринансовый анализ. 2010. № 6. С.32-62.

4. Богомолов В. А. Экономическая безопасность. Москва : Юнити-Дана, 2009. 295 с.

5. Болгар T. М. Фінансова безпека банків в умовах ринкової трансфоормації економіки України : дис... канд. екон. наук : 08.00.08. Дніпропетровськ, 2009. 212 с. С.98.

6. Артеменко Д. А. Механизм обеспечения финансовой безопасности банковской деятельности : авторефр. дис. ... канд. экон. наук : 08.00.10. Ростов-на-Дону, 1999. 32 с.

7. Землячов С. В. Управління банківськими ризиками при формуванні банками ресурсів. Науковий вісник. Фінанси, банки, інвестиції. 2014. № 2. C.77-82.

8. Янковский И. А. Прогнозирование показателей ликвидности банка с применением статистической имитационной модели : авторефр. дис. ... канд. экон. наук : 08.00.13. Минск, 2010. $21 \mathrm{c}$.

9. Алексеева Д. Г. Банковская безопасность: правовые проблемы : дис. ... д-ра юрид. наук : 12.00.14. Москва, 2011. 58 c.

10. Вишняков И. П. Направления устойчивого развития региональной банковской системы в современных условиях : дис... канд. экон. наук : 08.00.10. Ростов-на-Дону, 2018. 190 c.

11. Симановский А. Ю. Регулятивные требования $к$ капиталу: возможны ли альтернативы? Деньги и кредит. 2008. № 7. C.11-24.
12. Морозова О. А. Трансорертное управление ресурсами банка как элемент интегрированной системы фринансового менеджмента: подходы к автоматизации. Мир новой экономики. 2016. № 3. С.74-82.

\section{References}

1. Gayduk, V. I., Vorokov, A. L., Gay$d u k$, N. V. (2015). Finansovaya bezopasnost kommercheskikh bankov: kriterii i indikatory [Financial security of commercial banks: criteria and indicators]. Nauchnyi zhurnal KubHAU - Scientific Journal KubNAU, 114. Available at: http://ej.kubagro. ru/2015/10/pdf/06.pdf.

2. Rodchenko, S. S. (2019). Vartisno-oriientovana stratehiia zabezpechennia finansovoi bezpeki komertsiinykh bankiv [Cost-oriented strategy for ensuring the financial security of commercial banks]. (Thesis 21.04.02) [in Ukrainian].

3. Natocheyeva, N. N. (2010). Finansovaya bezopasnost bankov $v$ sfere mezhdunarodnykh raschetov i platezhey [Financial security of banks in the field of international settlements and payments]. Audit i finansovyi analiz - Audit and Financial Analysis, 6, 32-62 [in Russian].

4. Bogomolov, V. A. (2009). Ekonomicheskaya bezopasnost [Economic security]. Moscow: YunitiDana [in Russian].

5. Bolhar, T. M. (2009). Finansova bezpeka bankiv $v$ umovakh rynkovoi transformatsii ekonomiky Ukrainy [Financial security of banks in the conditions of market transformation of Ukraine economy]. (Thesis 08.00.08) [in Ukrainian].

6. Artemenko D. A. (1999). Mekhanizm obespecheniya finansovoi bezopasnosti bankovskoy deyatelnosti [The mechanism for ensuring the financial security of banking]. (Thesis 08.00.10) [in Russian].

7. Zemliachov, S. V. (2014). Upravlinnia bankivskymy ryzykamy pry formuvanni bankamy resursiv [Management of bank risks in the formulation of resources by banks]. Naukovyi visnyk. Finansy, banky, investytsii - Scientific Journal. Finance, Banks and Investments, 2, 77-82 [in Ukrainian]. 


\section{РИНОК ФІНАНСОВИХ ПОСЛУГ}

8. Yankovskii, Y. A. (2010). Prohnozirovaniye pokazateliyi likvidnosti banka $s$ primeneniyem statisticheskoy imitatsionnoy modeli [Forecasting indicators of bank liquidity using a statistical simulation model]. (Thesis 08.00.13) [in Russian].

9. Alekseieva, D. H. (2011). Bankovskaya bezopasnost: pravovye problemy [Bank security. Legal problems]. (Thesis 12.00.14) [in Russian].

10. Vyshniakov, Y. P. (2018). Napravleniya ustoychivoho razvitiya rehionalnoy bankovskoy sistemy $v$ sovremennykh usloviyakh [The directions of sustainable development of the regional banking system in modern conditions]. (Thesis 08.00.10) [in Russian].
11. Simanovskiy, A. Yu. (2008). Regulyativnyie trebovaniya k kapitalu: vozmozhny li alternativy? [Regulatory capital requirements: are alternatives possible?]. Dengi i kredit - Money and Credit, 7, 11-24 [in Russian].

12. Morozova, O. A. (2016). Transfertnoye upravleniye resursami banka kak element intehrirovannoiy sistemy finansovoho menedzhmenta: podkhody $k$ avtomatizatsii [Transfer management of bank resources as an element of an integrated financial management system: approaches to automation]. Mir novoy ekonomiki - The World of the New Economy, 3, 74-82 [in Russian].

Стаття надійшла до редакції 24.05.2021. 